DEPARTMENT OF FOOD AND RESOURCE ECONOMICS

UNIVERSITY OF COPENHAGEN

IFRO Working Paper

Jatropha Potential

on Marginal Land in Ethiopia:

Reality or Myth?

Mengistu Assefa Wendimu 


\section{IFRO Working Paper 2013 / 17}

Jatropha Potential on Marginal Land in Ethiopia: Reality or Myth?

Author: Mengistu Assefa Wendimu

www.ifro.ku.dk/english/publications/foi series/working papers/

Department of Food and Resource Economics (IFRO)

University of Copenhagen

Rolighedsvej 25

DK 1958 Frederiksberg DENMARK

www.ifro.ku.dk 


\title{
Jatropha Potential on Marginal Land in Ethiopia: Reality or Myth?
}

\author{
Mengistu Assefa Wendimu \\ Danish Institute for International Studies (DIIS) \\ Natural Resources and Development Group \\ Østbanegade 117, DK-2100 Copenhagen, Denmark \\ Email: $\underline{\text { mas@diis.dk }}$ \\ and \\ Department of Food and Resource Economics \\ University of Copenhagen \\ Rolighedsvej 25, DK-1958 Frederiksberg C, Denmark
}

\begin{abstract}
Rising oil prices, concerns about climate change, and future energy supplies have contributed to growing interest in the use of liquid biofuels in the transport sector which, in turn, has driven large-scale land acquisitions in developing countries for biofuel feedstock production, mainly jatropha. The increasing trend of land acquisition for biofuels has led to the widespread debate about food versus biofuel because of the perceived competition for land and water. To avoid the food versus fuel debate, the use of "marginal" land for biofuel feedstock production (jatropha) has emerged as a dominant narrative. But both the availability and suitability of "marginal” land for commercial level jatropha production is not well understood/examined, especially in Africa. Using a case study of large-scale jatropha plantation in Ethiopia, this paper examines the process of land identification for jatropha investments, and the agronomic performance of large-scale jatropha plantation on so-called marginal land. Although it has been argued that jatropha can be grown well on marginal land without irrigation, and thus does not compete for land and water or displace food production from agricultural land, this study indicates that moisture stress is the key factor in the failure of many large-scale jatropha plantations in Ethiopia.
\end{abstract}

JEL classification: Q15, Q16, Q42

Key words: biofuels; jatropha; marginal land; large-scale; Ethiopia 


\section{Introduction}

Increasing fuel prices, concerns with climate change and future energy security have led to tremendous global interest in the use of liquid biofuels in the transport sector (Schut et al. 2010, World Bank 2010, German et al 2011). Liquid biofuel has attracted the interest of governments and policy makers because of its immediate usability in the existing transport sector and the ease with which it can be blended with fossil fuels (Borras et al. 2011). The increased interest in the use of biofuels in the transport sector, together with the favourable policy environment for biofuels both in developed and developing countries, has led to intensified land acquisitions for large-scale biofuel feedstock production in Africa. The enthusiasm for the use of liquid biofuels was followed by the global food and economic crisis of 2007/08, both of which further aggravated the rate and scale of land acquisitions for food crops and biofuel feedstock production (PRAI 2010). Borras et al. (2011) argue that the growing demand for biofuels will not be sufficiently met, even if all the currently cultivated land in the United States and the European Union were converted to biofuel production. Thus, as part of the solution to the interlinked food and oil price crisis, and as a response to the food versus fuel discourse due to the competition between biofuels and food crops for land and water, a dominant narrative has emerged which suggests the existence of global agricultural land reserves that are "marginal or under-utilised" (Borras et al. 2011, Makki and Geisler 2011). This narrative advocates the transformation of these "marginal or under-utilized" land into zones for food and biofuel production, resulting in a "win-win" solution to food and energy security concerns. However, the assumption about the availability of "marginal" land that can be used for large-scale biofuel feedstock production, either on a global or national level, and the effects of such large-scale land conversion on social, economic, and environmental systems, raised serious concern among academics, civil societies and NGOs even before the emergence of the global food price crisis (UN-Energy 2007, IFAD 2008).

Ethiopia has portrayed itself as one of the countries with the highest potential for biofuels in Africa, and the government has proposed about 23.2 million hectares of "marginal" land be converted for biofuel feedstock production, mainly jatropha. The Ethiopian government's arguments for the use of "marginal" land are based on two assumptions: (i) there is ample "marginal" land in the country, and (ii) biofuel feedstock (jatropha) can be commercially grown on so-called marginal land. Although the Ethiopian government and other proponents of biofuels argue that "marginal" land can be used for biofuel feedstock production such as jatropha, this claim is not supported by studies that thoroughly examine the actual biofuel investments on the so-called marginal land. In this paper, by arguing that the unsupported assumptions are not only flawed but also misleading, I examine the narratives of "marginal" land availability, and the experience of growing jatropha on marginal land, by answering the following two main questions: (i) how is "marginal" land identified and quantified in Ethiopia? And, (ii) what is the agronomic performance of jatropha on the so-called marginal land.

The remainder of the paper is structured as follows. Section two presents the method used in the study. Section three discusses the development, in Ethiopia, of the biofuels sub-sector, biofuel policy drivers and means of supporting policy to achieve targets. Section four and five examine the different perspectives on marginal land and the contested claims about jatropha performance on so called marginal land through a review of the existing literature. Section six relates the assumptions that led to the drastic failure of an East African large-scale groundnut scheme in present day Tanzania to the current assumptions used to promote largescale jatropha production in Africa. Section seven describes marginal land identification and 
the quantification process in Ethiopia. Section eight presents a case study of large-scale jatropha production in Ethiopia, and discusses the major reasons for its failure. Finally section nine provides some concluding remarks.

\section{Research Method}

The field work for this research was conducted in West Hararge Administrative Zone (Mieso District) in Oromia Regional Governmental State of Ethiopia between December 2011 and February 2012. Pastoral and agro-pastoral production systems are the two common agricultural practices in the district, which has a total area of 176,026 ha with altitude ranging between 900-1600 meters above sea level (Feto 2011). The annual rain fall of the district ranges between 400 and $900 \mathrm{~mm}$ with a mean value of $790 \mathrm{~mm}$. It was planned to conduct this study in more than one region in Ethiopia. Although about 85 companies were licenced in Ethiopia to invest in biofuels, mainly jatropha, there was only one active jatropha investment project during the study period that was suitable for the study, because all the other projects were still in the implementation phase or had not started at all. As a result, the case study was limited to the Emami Biotech's jatropha plantation in Bordode Kebele.

A qualitative case study approach was mainly employed to conduct this research. An in-depth investigation of the Emami Biotech's jatropha investment using key informant interviews was conducted at the national level at the newly established Ethiopian Investment Directorate under the Ministry of Agriculture, the Ethiopian Biofuels Development Directorate, and the Ethiopian Investment Agency. At the regional level, interviews were conducted at the Oromia Bureau of Mines and Energy and the Oromia Investment commission, while at the district level, interviews took place at the Miesso Agricultural Office. Finally, at the local level, interviews were conducted with development agents and community members in Bordode Kebele, where Emami Biotech's jatropha plantation is located. The interviewees at the local level were mainly asked to describe the land acquisition process, consultation issues, compensation (if any), and the positive and negative effects of the investment on the local community. During the interviews, the participants were able to describe their views and opinions about the project's impact which enabled the researcher to better understand the Emami Biotech's jatropha investment and the situations which led to its termination. Although it was not possible to interview the project staff as the company abandoned its operation during the field work, data was collected from local ex-project employees. To better understand the jatropha investments in Ethiopia, additional interviews were conducted with the director of the Horn of Africa Regional Environmental Centre and Network, project managers of African Power initiatives, ATIRF Alternative Energy PLC and Fri-Elgreen Power Ethiopia, of which the latter two companies were at the pre-implementation phase of large-scale jatropha plantation in the southern part of Ethiopia. Field visits were also conducted at Emami Biotech's abandoned jatropha plantation in Bordode Kebele and in the northern parts of the country (Bati and Kemise), where jatropha is grown to form hedges around homesteads and farm land.

\section{Biofuel development in Ethiopia}

In Ethiopia, large-scale investments in biofuels have a recent history with the first large-scale biofuel feedstock production being established in 2006 by the UK-based biofuel company, Sun Biofuels. Since 2006, Ethiopia has become a major destination for Foreign Direct 
Investment (FDI) in biofuels in Africa. Although most of the biofuel investments have not yet been implemented, in 2011, the amount of capital that the biofuel companies committed to invest in biofuels represented up to 50\% of FDI flow at the national level (Bossio et al. 2012). Within four years, the interest to invest in biofuels increased massively so that, in 2010, about 83 companies had been granted a licence to invest in biofuels (Ethiopian Biofuels Directorate 2010). According to the recent land deals matrix released in April 2012 by the International Land Coalition (ILC), in Ethiopia, about 1,360,670 ha of land was reported to be leased for biofuel projects out of which more than 700,000 hectares of land was leased for jatropha projects (Land Matrix 2012).

There are two main policy driving forces that are assumed to have contributed to the dramatic increase in the number of planned biofuel projects in Ethiopia. The first driving factor was the government's desire to secure its national energy by producing biofuels from domestically grown feedstock (MoME 2007). As Ethiopia is a landlocked and non-oil producing country, its economy is fully reliant on imported oil and is highly vulnerable to higher international oil prices. In addition to the increasing oil prices, the country's oil demand is also increasing rapidly due to rapid economic growth and the expansion of its transport sector. Thus, the high oil prices and the increasing demand for oil in the country forced the government to look for alternative energy sources that were available domestically.

The second driving force was the increasing demand for biofuels at the global level. The EU energy directive of 2009 endorsed a mandatory target of a 20\% share of energy from renewable sources in the overall energy consumption and a mandatory $10 \%$ minimum target to be achieved by all member states of the EU, mainly from biofuels in the transport sector, by 2020 (EU Directive 2009). The directive claims that since transport fuels can be easily traded, member states with lower domestic resource endowments will be able to meet the target by importing biofuels from elsewhere.

To support the development of the biofuel sector in the country, the Ethiopian government has made two main policy amendments. First, in 2009, the government introduced an ethanol blending policy that sets a blending mandate of $5 \%$ ethanol with $95 \%$ gasoline. The blending mandate was increased to $10 \%$ in early 2011 and there is a plan to increase it further to $25 \%$ in 2014. Secondly, the government has made many amendments to its agricultural development and taxation policies to attract investments in large-scale agricultural projects including biofuels. Desalegn Rahmato, head of the Ethiopia Forums for Social Studies, described this as an "open door policy" that provides many incentives to attract investors to invest in biofuels and other agricultural projects (Rahmato 2011). The increased demand for biofuel investments in the country has resulted in the preparation of the ambitious biofuels policy document entitled 'The Biofuels Development and Utilization Strategy of Ethiopia` in 2007 (MoME 2007). The main assumptions underlying the focus on biofuels as an alternative energy source, according to the strategic document, are the availability of relatively cheap labour that can make biofuels competitive with petroleum oil, the "availability" of a large amount of suitable "marginal” land for biofuel production, and the presence of diverse soil and climate conditions suitable for the production of different types of biofuel feedstock. However, the strategy, which was developed mainly based on resource "availability" assumptions, has triggered criticism from local NGOs, civil society and development partners. While the proponents, mainly the government, have seen biofuels as an opportunity to ensure national energy security, as a means to earn hard currency, and a way of modernizing the agricultural sector and increasing rural income, others have strongly argued that conversion of large tracts of land for biofuels will have negative consequences for rural communities, national food security and biodiversity in the country (Lakew and 
Shiferwa 2008). Thus, to avoid these criticisms the government stated that only "marginal" land will be used for the production of biofuels. The next section presents a summary of previous studies on "marginal” land in a developing countries context.

\section{4. “Marginal” land: From whose perspective?}

Jatropha has received tremendous attention in most African countries and has emerged as one of the most promising feedstock candidates for the production of liquid biofuels, both at small-scale and large-scale commercial level. Hence, the governments of most developing countries who aim to attract foreign investments in biofuels, and those in the developed world, are promoting claims that there is ample "marginal" land in Africa and that jatropha can be successfully grown on "marginal" land without affecting food security or the livelihoods of rural communities. However, some recent empirical studies have challenged these claims (Ariza-Montobbio et al. 2010, Borras et al. 2011, Rachel 2012, Royal Society 2008).

The term marginal land was first defined by Peterson and Galbraith (1932) from a purely economic perspective as land on the "margin of cultivation". According to Dale et al. (2010), the construction of "marginal" land is context dependent and its definition varies widely by country, local conditions, and the organizations studying the issue. While in economic terms, land is marginal if the combination of yields and prices barely cover the costs of production, in practice the term is generally used broadly to describe land that is not in commercial use in contrast to land yielding net profits from the services (ibid). Depending on time and space, the term marginal land may refer to idle, under-utilized, barren, inaccessible, degraded, excess or abandoned land, or land that is occupied by politically and economically marginalized populations (ibid). Bailis and Baka (2011), while they acknowledge that no single definition exists for marginal land, indicate that the term describes land that is perceived by outsiders as unused, often governed by common property rights, and of little productive value. They also state that the marginal land designation is applied in a homogenizing way, concealing the wide range of land types, tenure relations, and socialecological interactions that characterize land falling under the broad category of marginal land.

Milbrandt and Overend (2009), in their study which aims to estimate the extent of marginal land in 19 countries of the Asia-Pacific Economic Corporation (APEC), stated that the term "marginal land" appears to be used quite loosely without a specific definition. Jonasse (2009) also points out that the terms "marginal" or "idle" land are deliberately vague, and that misuse of the terms is enabling massive land allocation to investors who are destroying biodiverse ecosystems and displacing people from their land. Despite the fact that the term marginal land is widely used in academic literature, it is not supported by a particular definition or research to determine which land falls into this category (James 2010). Thus, it is crucial to understand what "marginal" means in order to determine which land is actually "marginal" (ibid). James (2010) emphasises that use of the term "marginal land" as a basis for policy making is problematic, even if the term is well understood, because the status of "marginal" land by definition is relative and changeable depending on land use type and changes in price or policy.

Not surprisingly, there is also no specific definition of what constitutes marginal land in Ethiopia. Although the Biofuels Development and Utilization Strategy document states that "marginal" land will be used for biofuels, it does not indicate what kinds of land are 
classified as marginal. However, the government policy documents often associate marginality with low moisture and poor soil quality. Nevertheless, land that is marginal for crop production often provides a key subsistence function for poor rural communities (Gopalakrishnan et al 2011). Thus, defining marginality only in terms of agro-economic profitability undermines the importance of this land for rural poor communities and pastoralists, especially in countries like Ethiopia where pastoralism is one of the major sources of livelihoods in dry low land areas. The next section examines, through a literature review, the potential of jatropha on marginal land.

\section{The contested claims about jatropha potentials on marginal land}

Jatropha has attracted unique attention from researchers, policy makers and industries as one of the most promising biofuel feedstock candidates (Kesava Rao et al. 2012). Many claims have been made about jatropha as a potential biodiesel crop and it has been hailed as a "miracle" crop that can resist drought and grow well on "marginal" land, and a crop that can help to reclaim degraded land (FAO 2008). It has also been described as a "miracle tree" that can alleviate energy crises and generate income in rural areas in developing countries (Trivedi et al. 2009); a unique and ideal biodiesel feedstock candidate that can be grown on "marginal" land to produce biodiesel without competing for land currently used for crop production (Trivedi et al. 2009, Kesava Rao et al. 2012, Yang et al. 2012, Pandy et al. 2012); "green gold" which is superior both in terms of the global environment and the economy than any conventional biofuel crops grown in temperate climates (Renner, 2007); and a "new magic bullet" that can easily cure the complex prevailing problems of energy security, climate change and rural development (Dyson 2007). Trivedi et al. (2009) described jatropha as a crop that is becoming a poster child among some proponents of renewable energy, particularly as an oil-bearing, "drought resistant" tree for marginal land for small farmers. The 2007/08 global food price crisis, which many studies linked to the diversion of food crops such as corn and soybean to biofuels, has further helped jatropha gain priority on the global biofuel agenda of policy makers, NGOs and renewable energy industry leaders. Since then, jatropha has been presented as a biofuel feedstock which does not involve a trade-off between food and fuel by its advocates who have promoted it for extensive plantation on "marginal” land throughout the world (Pandey et al. 2012).

The claims about jatropha as a "miracle" crop have inspired oil companies and companies investing in renewable energy to invest in large-scale jatropha plantations in Africa, Asia and Latin America (Green Car Congress 2009). Although the positive claims made about jatropha have led to the establishment of many large-scale jatropha plantation projects all over the world, mainly in the global South, the crop has so far failed to prove the associated claims in reality. Many recent studies argue that most of the claims made about jatropha are myths. A study conducted in Mozambique by JA \& UNAC (2009) concluded that the dominant arguments about jatropha as a food-security safe biofuel crop, a source of additional farm income for rural farmers, and a potential driver of rural development, were misinformed at best and dangerous at worst. D1 Oils, one of the major players in the biofuel industry, also concluded, based on their own research and experience with jatropha, that the claims being made about the crop, including that it can grow under marginal conditions, is pest and disease resistant, and does not require fertilizer, are simply not true (Volckaert 2009). Volckaert concludes that jatropha is not a "miracle" crop as, just like any other cultivated crop, it needs proper management, proper genetic selection and commercial cultivar development and 
conventional crop inputs. Based on his study conducted in Mozambique to assess the potential of jatropha as a biodiesel feedstock, Begne (2006) articulated his concerns about the myths of jatropha by relating it to the old saying "there is no free lunch". He argued that, although Jatropha may look promising as a tree/shrub for marginal land, without added nutrients, moisture and improved germplasm, marginal yields can be expected. Behera et al. (2010) also state that the production of jatropha on marginal land for biofuel without the use of large inputs has recently created a hype of attention, resulting in the planting of huge areas of jatropha in Asia, Africa, and Latin America. Many other earlier studies conducted in Africa and India, where jatropha has been vigorously promoted, have also shown that although jatropha can survive on land with low nutrients and moisture, it needs sufficient nutrients and irrigation to be profitable on a large-scale commercial level (Endelevu Energy 2009, Milbrandt and Overend 2009, Ariza-Montobbio 2010).

Another dominant argument to promote jatropha was the assumption that jatropha requires less water than other biofuel crops like corn, soybean and sugarcane, so that it can be grown on marginal land to avoid competition with food crops for arable land. However, a study by Gerbens-Leenes et al. (2009), which analyzed the water footprint of bioenergy crops, ranked jatropha as the crop with the highest water footprint when grown under optimal conditions among the 12 crops considered in their study, which included maize, sugarcane and rapeseed. Despite the claims made about the potential of jatropha as a biofuel feedstock, the jatropha plantation projects which have been initiated in Ethiopia to date have not realised these claims that drove the "Jatropha euphoria". The next section explores the assumptions which underpin present large-scale jatropha projects and the unsuccessful post-colonial East African large-scale groundnut scheme.

\section{Learning from History? The East African Groundnut Scheme}

The problems with large scale jatropha plantation as observed in Ethiopia may have much in common with earlier policies in the region, in particular with the East African Groundnut Scheme which, as will be outlined below, is a classic example of disastrous programme failure.

The global fats and oils shortage that occurred following World War II led to the initiation of the East African groundnut scheme in Tanganyika (the present day Tanzania) in 1946 by the British Government (Hegendorn and Scott 1981, Morgen 1980, Rizzo 2006). The initial proposal to establish mechanized large-scale groundnut production came from Samuel Franks, the managing director of the African United Company (AUC), a subsidiary of Unilever, a multi-national giant that supplied about three-quarters of the margarine consumed in Western Europe and two-third of soaps utilized in the UK and its colonies. Samuel Franks, following his visit to Tanganyika, suggested to the British Minister of Food a scheme to grow groundnut on 3.1 million acres in the "empty spaces" of East Africa to fulfil Britain's critical shortage of oils and fats (Kauzeni et al 1993). The general idea was accepted by the Minister, while several questions remained unanswered (ibid). The plan was approved by the British government in December 1946, and the implementation of the project began in February 1947 with desperate urgency. The scheme was expected to produce 600,000 tonnes of peanuts by the fifth year and the total cost of the project was estimated to be $£ 24$ million. After five years, the outcome of the scheme in practice was a total failure. While the targets for the scheme were reduced year after year, its cost was progressively adjusted upwards. 
When the project was shutdown in 1951, over $£ 36$ million had been spent, while the scheme had imported more groundnuts as a seed than it actually produced (ibid). According to Rizzo (2006), the East African Groundnut Scheme in Tanganyika is probably the most dramatic and most cited failure of the ambitions of the late British colonial development projects in Africa.

The main assumptions underlying the initiation of the failed late-colonial East African groundnut scheme and the present day jatropha projects in Africa are very much related to each other. Among the main assumptions are: (i) while large-scale jatropha production is being promoted by the narratives of the use of "marginal" land, "empty" land narratives were used by the post-colonial British government to confiscate land from its users. Both narratives do not look into the issues of whether there are insuperable objections from the point of view of native land users, (ii) the selling point, both for the jatropha projects and the East African groundnut scheme, was that the projects would bring development to Africa, though the main aim was to look for a solution to the problems that countries in Europe faced at home, (iii) the sense of urgency with which the projects were initiated, as in both cases, very superficial feasibility studies were conducted, mainly areal mapping, and large-scale projects were initiated without pilot testing, and (iv) assumptions that the existing conditions, such as soil conditions, temperature, precipitation, were suitable for the crops under consideration without the existence of any credible scientific evidence to support these claims. The fact that similar factors, which led to the drastic failure of the East African ground nut schemes more than six decades ago, are also responsible for the present-day failure of largescale biofuel projects in general, and jatropha in particular, shows that we have not learnt from past failures. The remaining sections comprise a case study from Ethiopia which examines the procedures for the identification of marginal land and its quantification, and the agronomic performance of jatropha on this so-called marginal land.

\section{Marginal land identification and quantification process in Ethiopia}

The previous sections have attempted to highlight the concept of marginality and the different claims made about jatropha's potential on marginal land. This section examines how marginal land is identified and quantified in Ethiopia. Jingura et al. (2011) reveal that determining the potential availability of land for biofuels is a non-trivial task and the suitability of the land for the production of biofuels such as jatropha can also not be taken for granted, particularly when the concept and practice of biofuels remains contested due to the threat they pose to food security.

This case study reveals that there is no agreed upon national procedure for the identification and quantification of the so-called marginal land in Ethiopia. The main criteria used for the identification of "marginal" land in the country are the quality of the land and its current use type. Land quality is elaborated in terms of the land's potential to support agricultural crop production. The Ethiopian Government Biofuel strategic document claims that the land allocated for biofuel production, mainly jatropha, cannot support any agricultural crops because of its low moisture content or due to poor soil quality. The second criterion used is the land that is identified as marginal has no current users. The quantification of marginal land also takes two forms: remote sensing and estimation using local knowledge. The gross estimations at the national and regional levels made by the federal authorities are usually made using remote sensing technologies. At the district and village level, the quantification of "marginal" land is conducted by the respective district and village level agricultural offices based on local knowledge. In the Oromia region, village level agricultural office branches 
make the assessment of "marginal" land availability in their territory and make the estimation of "marginal" land based on the information from the local area, and report to the respective districts, which in turn have to report to the regional Environment and Land Office. For consolidated land size greater than 5000 ha, the regional Environment and Land Office has to report to the Federal Agricultural Investment Support Directorate.

Although it has been argued by government officials that remote sensing technologies, in combination with ground verification of the remote measurements should be used, the experiences so far show that these techniques are ineffective. One classic example of the ineffectiveness of these methods can be demonstrated by a case where a German biofuel company, called Flora Eco Power, was given 13,000 ha of what was considered "marginal" land for the production of castor oil for biodiesel in the East Harerge district of Oromia region, although about $87 \%$ of the land was later found to be part of the Babile Elephant Sanctuary (African Biodiversity Network et al. 2008). The land was allotted to the company based on land use information obtained from satellite images and information from the district level agricultural office. However, when the company started to clear the land of forest, opposition came from the Ethiopian Wild Life Society and local environmental NGOs, which finally led to the relocation of the project to a nearby location covered by acacia trees. Rachel and Dana (2012) have also pointed out that, although modern remote sensing technologies are used in determining the availability of "marginal" land, the use of these technologies has serious limitations for two main reasons: people frequently have uses for the land that are not reflected in land use dataset, such as the social and cultural value of land, and a remote classification of marginality is incapable of capturing the changing nature of land use. The experience on the ground shows that not all the criteria for the identification of marginal land, which is, according to the biofuel strategy document, land that has no current users and which is incapable of producing agricultural crops, are met. For instance, the land that was given to Emami Biotech, the biofuel company which is the focus of this case study, was grazing land used by pastoralists in the area. The following section examines the case of Emami's jatropha plantation in Ethiopia.

\section{The case of Emami Biotech jatropha plantation}

\subsection{The company background}

In 2009, Emami Biotech Limited, an Indian firm based in Calcutta, established its first overseas biofuel investment in the West Hararge Administrative Zone (Mieso District) in the Oromia Regional Governmental State of Ethiopia. In August of the same year, the company announced that it had leased 11,000 ha of land in the first phase with a renewable lease agreement of 45 years from the Oromia Investment Commission out of the 40,000 ha promised for the company's future expansion (The Financial Express 2009). The company had planned to invest US \$83 million for the establishment of large-scale jatropha plantations and a biofuel processing plant closer to the plantation site over the investment period of five to six years. On its completion, it was estimated that the processing plant would have a processing capacity of 100,000 tonnes of crude-biofuel per year. By the end of 2010, the company had planted jatropha on 700 hectares of land. However, after less than two years in operation, Emami Biotech abandoned its jatropha plantation at the end of 2011. The next section examines the main reasons that led to the failure of Emami's jatropha project in Ethiopia. 


\subsection{Poor jatropha performance on “marginal” land}

An analysis of the Emami Biotech case revealed that the poor agronomic performance of jatropha plantation was one of the main reasons for the closing down of the company's operations. Ariza-Montobbio and Lele (2010) have used seedling survival rate, vegetative growth, and yield as a proxy for agronomic performance. The survival rate of jatropha at Emami Biotech farm was $77.7 \%$ (Feto 2011). This finding is very similar to the study by Ariza-Montobbio and Lele (2010) in which they report a $80 \%$ survival rate under rain fed conditions. Montobbio and Lele (2010) reported a 99\% survival rate under irrigation, and they also showed that the average number of nuts per plant was twice as high in irrigated plots compared to rain fed conditions. Although the Emami jatropha plantation had a reasonable survival rate, the jatropha growth rate was extremely low. The average height of the plant was estimated to be less than 1.5 meters after one and half years, which is when the plant is expected to bear the first fruit. The company did not harvest any yield before it abandoned its jatropha farm. Two main factors contributed to the poor performance of Emami Biotech's jatropha plantation. The first was moisture stress as the investment project was located in a lowland area where the amount of annual rainfall is minimal and erratic (less than $750 \mathrm{~mm}$ per annum). According to Feto (2011), Emami Biotech had tried to develop a series of farm ponds, mini dams and gully plugging to harvest and store water from flash floods for use in irrigation during the dry period. Since the harvested surface water was insufficient to irrigate the whole field during the extended dry period, the company also conducted a hydro-geological assessment of ground water, which was also found to be uneconomical because of the great depth of the underground water in the area. Based on an evaluation of jatropha performance under different agro-ecologies, Behera et al. (2010) concluded that irrigation is one of the critical inputs for jatropha cultivation in dry areas, especially during its initial establishment. They specified that, although jatropha can be grown without irrigation from $250 \mathrm{~mm}$ up to $3000 \mathrm{~mm}$ per year, irrigation at regular intervals, especially during the establishment period, along with standardized agronomic practices, are necessary to achieve higher yields. Openshaw (2000) and Pandy et al. (2012) also show that jatropha seed yield ranges from about 0.4 to over $12 \mathrm{t} / \mathrm{ha} /$ year after five years, where the amount of yield directly corresponds to the amount of precipitation and soil fertility.

The second crucial factor that led to the poor performance of jatropha was the fact that the company used untested planting materials. The plants were propagated from seeds, although jatropha is strongly heterozygotic and the propagation of high yielding and high quality genotypes requires clonal or tissue culture techniques (Sarathum et al. 2011). According to Feto (2011), the company used seeds collected from the different parts of the country where jatropha grows naturally, and imported seeds from India. However, an evaluation of the agronomic performance and commercial viability of the planting materials was not conducted under the existing local soil and climatic conditions. Breeding and agronomic research on jatropha in Ethiopia is very scarce, and only a few research centres, such as Melaksa Agricultural Research Centre and Wendo Genet Forestry Research Centre, have recently started jatropha germplasm selection trials. Melkassa Agricultural Research Centre has conducted a jatropha germplasm selection trial at the Miesso research station, which is around $50 \mathrm{~km}$ from the Emami Biotech jatropha plantation in Bordede. During the field work, it was observed that the vegetative growth performance of jatropha on experimental plots was not impressive. Since the results of the experimental trial have not yet been published, it was not possible to obtain yield and other agronomic data from the research station. Bereno et al. 
(2011) confirm that the selection of basic planting material is a crucial step and a tree which has an annual yield above $2 \mathrm{~kg}$ dry seeds and a seed oil content which is higher than $30 \%$ by weight can be considered a good source of planting material. Bereno et al. (2011) have also admitted that sufficient information about the plant's nutrient needs and water requirements in different ecosystems is still lacking even in India, where a lot of research has been conducted on Jatropha.

\subsection{Conflict over the land}

The Emami jatropha project is located in a neighbourhood where there is a historical conflict between two ethnic groups (Afar and Oromo) over grazing land. The communities in the project area are mainly pastoralists and very few of them are engaged in mixed crop-livestock activities. There is a large-tract of land lying along the border of the two regions (Afar and Oromia) which was used as a conflict buffer zone between the two ethnic groups. However, due to the increasing scarcity of grazing land in the area caused by the expansion of largescale private and government farms in the middle Awash area (Hundie 2010), competition for grazing land is increasing and aggravating armed conflicts between the two ethnic groups. Historically, the conflict between the two ethnic groups has been sporadic and mainly limited to the dry season, but now the conflicts are becoming more frequent even in the rainy season due to the gradual decline of grazing land. It is in this area, within the Oromia region, that Emami Biotech received 11,000 ha of land for its projects. While the grazing land in the Afar region is being squeezed by the expansion of large-scale private and government cotton farms, the Emami project was perceived to squeeze the grazing land in the Miesso district of Oromia region.

Since all land in Ethiopia is officially owned by the state, the users of the land that was allocated to the Emami jatropha project were not consulted and they were not part of the negotiation process, and they had to accept the top down decision made by the government to lease the land. Although the government strongly argued that the land allocated to Emami Biotech was "marginal”, free from inhabitants and unsuitable for agricultural crop production, the land was communal and was mainly used for livestock grazing. Moreover, the land was used for income generating activities, mainly the sale of charcoal and fire wood. The creation of employment opportunities and the development of infrastructure such as schools, rural health stations and water wells were used to convince project affected communities to accept the project, which was going to be implemented anyway. However, the communities were not informed about the time frame within which the promises made by the company will be materialized. As one of the key informants who used to work for the Emami project explained, after project implementation, the local community started to ask for the promises made by the company. According to the information from the Miesso district agricultural office that monitors the investment, the company created jobs for about 160 people during the initial phase of the project for land clearing, land preparation and the planting of jatropha seedlings, though the number of employees was significantly reduced once jatropha planting was completed. The company's inability to generate sufficient jobs that could engage the majority of affected people, and the urgency from the community side to get the promised infrastructure finally led to a conflict between the company management and the previous land users, which consequently created a sense of insecurity among the project staff who had to work and live in the area. A key informant, who wanted to be anonymous, explained that unknown groups from the local community made many attempts to attack the project staff and the company's project manager. The project finally came to an end due to the 
disappointing jatropha performance and the insecurity among the project staff in the area due to conflict over the unmet promises.

Similar large-scale jatropha plantation failures were reported from different regions in Ethiopia. In 2006, Sun Biofuels was granted 80,000 ha of land with a lease period of 50 years at a lease price of 25 birr/ha/year (less than \$2) in the Metekel Zone of the Benishangul Gumz region for jatropha plantation (Lakew and Shiferwa 2008). After clearing 60 hectares of forest land and planting some of the cleared land with jatropha seedlings, the company ceased operations due to the unsuitability of the soil for jatropha plantations (ibid). The problem in this project was that the soil was a heavy black soil that suffered from deep cracks during the dry season. This cracking meant that most of the jatropha seedlings dried out and it became extremely difficult to establish a farm. In the same year, Sun Biofuels was given 5,000 ha of pasture land that was considered "marginal" by government officials for jatropha plantation in the Wolaita district in Southern Ethiopia. According to the study conducted jointly by the African Biodiversity Network, the Ethiopian Society for Consumer Protection and the Giga Foundation (2010), Sun Biofuels abandoned its large-scale jatropha plantation in Wolaita district in 2009 after three years of unsuccessful growing seasons, mentioning low rainfall and poor soil quality as the main reasons for the company's failure to produce a sufficient harvest from the jatropha plantation.

Most of the companies who received a licence to invest in biofuels have failed to commence implementation of their projects according to agreements, and therefore the Ethiopian Ministry of Agriculture has recently started repossessing land from these companies. Consequently, the Italian biofuel company, Fri-Eli, which previously leased 30,000 ha of land for jatropha plantation in Southern Ethiopia, became the first company to lose its land due its failure to implement the jatropha project according to the lease agreement. Moreover, most of the companies have already terminated their jatropha projects in Ethiopia. While some companies have officially announced the closing down of their jatropha projects in Ethiopia, many have terminated their projects and left the country without notification.

\section{Conclusion}

The most important conclusion that can be drawn from this study is that the claim that jatropha can be commercially grown for biodiesel on marginal land is an unproven argument which has played a major role in the failure of jatropha projects in Ethiopia. The identification and quantification of marginal land has also remained an elusive concept as different institutions employ different definitions and methodologies. The finding of this study suggests that prioritizing the use of remote sensing technologies without local level verification of the information, the current practice in use in Ethiopia, is unlikely to be an accurate method for the practical identification and quantification of marginal land. Currently, land marginality in Ethiopia is simply determined based on the productivity of land (whether the land is suitable for agricultural crop production or not). However, determining land marginality based only on its potential for crop production has serious limitations as it fails to recognize the complex reality of previous land uses, which often provide key livelihoods for rural communities and low-income groups, as illustrated by the Emami Biotech jatropha project case study. Regarding current biofuel projects, jatropha is mainly being promoted without sufficient scientific knowledge of the crop and its agronomic practices. Thus, promoting large-scale investments in jatropha may discourage any future investments in 
jatropha, while it may also lead to financial loss for actual investments. However, jatropha is still a wild plant with high heterozygosity so that its domestication and the development of appropriate technologies (e.g. selection of high yielding varieties; improved water, nutrient, and pest management; pruning; taproot development at cutting plants; seedling production of high performance clones through in-vitro culture; customizable root development) might considerably improve the performance of jatropha on "marginal" land in the future (Hegele 2012). However, for the time being, the potential for profitable jatropha production on "marginal" land in Ethiopia is not a reality, but a myth.

\section{Acknowledgment}

This research is part of the author's PhD study entitled Biofuel Development in Ethiopia: Impacts on access to land and welfare of the rural household and was fully funded by the Danish Ministry of Foreign Affairs. The financial support from the Ministry is greatly appreciated. The author is grateful to Peter Gibbon, Arne Henningsen, Margaret Skutsch, and Martin Hegele for their comments and suggestions which helped to improve the paper. 


\section{Reference}

African Biodivesity Network, the Ethiopian Society for Consumer Protection and the GIGA Foundation, 2010. Biofuels: A failure for Africa. Addis Ababa, Ethiopia.

Ariza-Montobbio, P. \& Lele, S. (2010) Jatropha plantations for biodiesel in Tamil Nadu, India: Viability, livelihood trade-offs, and latent conflict. Ecological Economics 70: 189-195.

Ariza-Montobbio,P., Lele, S, Kallis,G. \& Martinez- Alier, J., (2010). The political ecology of Jatropha plantations for biodiesel in Tamil Nadu, India, Journal of Peasant Studies 37(4): 875-897.

Bailis, R. \& Baka, J. (2011): Constructing Sustainable Biofuels: Governance of the Emerging Biofuel Economy. Annals of the Association of American Geographers 101 (4): 827-838

Behera, K. Srivastava, P., Tripathi, R., Singh, J.P., and Singh, N. (2010). Evaluation of plant performance of Jatropha curcas L. under different agro-practices for optimizing biomass - A case study. Jouranal of Biomass and Bioenergy 34(1):30-41.

Benge, Mike, 2006. Assessment of the potential of Jatropha curcas, (biodiesel tree,) for energy production and other uses in developing countries, Agroforestry Office, USAID.

Borras Jr,S., David Fig \& Sofía Monsalve Suárez, 2011. The politics of agrofuels and megaland and water deals: insights from the ProCana case, Mozambique. Review of African Political Economy 38(128): 215-234

Bossio, D., Erkossa, T., Dile, Y., McCartney, M., Killiches, F., and Hoff, H. (2012). Water Implications of Foreign Direct Investment in Ethiopia's Agricultural Sector. Journal of Water Alternatives 5(2): 223-242

Dale, V. H., S. Brown, R. A. Haeuber, N. T. Hobbs, N. Huntly, R. J. Naiman, W. E. Riebsame, M. G. Turner, and T. J. Valone. 2000. ECOLOGICAL PRINCIPLES AND GUIDELINES FOR MANAGING THE USE OF LAND1. Ecological Applications 10:639670.

Dyson, T., 2007. The New Magic Bullet. The palm beach letter, Daily Wealth (http://www.dailywealth.com/994/The-New-Magic-Bullet, retrieved 02-08-2012).

Endelevu Energy, 2009. Jatropha Reality Check: a field assessment of the agronomic and economic viability of Jatropha and other oilseed crops in Kenya. World Agroforestry Centre and Kenya Forestry Research Institute.

Ethiopian Biofuels Development Directorate (2011). Assessment of biofuels projects status in Ethiopia (Amharic version).

EU Directive, 2009. DIRECTIVE 2009/28/EC OF The European Parliament and of The Council of 23 April 2009 on the promotion of the use of energy from renewable sources and amending and subsequently repealing Directives 2001/77/EC and 2003/30/EC. Official Journal of the European Union L 140/16.

Feto, A (2011). Energy, greenhouse gas and economic assessment of biodiesel production from jatropha: the case of eastern and north eastern Ethiopia. MSc thesis, Haramaya University, Ethiopia. 
Gerbens-Leenes, W., Hoekstra, Y., and van der Meer, H. (2009). The water footprint of bioenergy. PNAS 106 (25): 10219-10223

German, L., G.C. Schoneveld and D. Gumbo. 2011. The local social and environmental impacts of smallholder-based biofuel investments in Zambia. Ecology and Society 16(4):12.

Gopalakrishnan, G., Cristina Negri, M., and Snyder., W. (2011). A Novel Framework to Classify Marginal Land for Sustainable Biomass Feedstock Production. Journal of environmental quality 40 (5): 1593-1600.

Green Car Congress, 2009. BP and D1 Oils from Joint venture to develop jatropha biodiesel Feedstock. Energy, Technologies, Issues and Policies for Sustainable mobility (http://www.greencarcongress.com/2007/06/bp-and-d1-oils-.html, retrieved, 02-08-2012).

Hegele, Martin, 2012, University of Hohenheim, Germany, personal communication in November 2012.

Hogendorn, S., and Scott, M. (1981). The East African groundnut scheme: Lessons of largescale agricultural failure. Journal of African Economic History 10(1981):81-115.

IFAD, 2008. Opportunities for Rural Poor People: How the poor can benefit from this emerging opportunity. Paper prepared for the Round Table organized during the Thirty-first session of IFAD's Governing Council. Prepared by Vineet Raswant, Nancy Hart and Monica Romano.

James, L., 2010. Theory and Identification of Marginal Land and Factors Determining Land Use Change .Paper provided by Michigan State University, Department of Agricultural, Food, and Resource Economics in its series Graduate Research Masters Degree Plan B Papers with number 98203.

Jingura, R., Matengaifa, R., Musademba, D., and Musiyiwa, K. (2011). Characterization of land types and agro-ecological conditions for the production of jatropha as a feedstock for biofuels in Zimbabwe. Journal of Biomass and bioenergy 35 (2011) 1050-1056.

Jonnase, R., 2009. Agrofuels in the Americas. Institute for Food and Development Policy. A Food First Books, Oakland.

Justica Ambiental and Uniao Nacional de Cammponeses (JA and UNAC), (2009). Jatropha! A socio - economic pitfall for Mozambique. Report prepared from SWISSAID.

Volckaert, V. (2009). Jatropha curcas: beyond the myth of the miracle crop. Regional Manager Africa -D1 Oils Plant Science, power point presentation.

Kauzeni, A., Kikula, I., Mohamed, S., and Lyimo, J. (1993). Land use planning and resource assessment in Tanzania: a case study. IIED Environmental Planning Issues No. 3 and IRA Research Paper No. 35.

Kesava Rao, R., Wani, P., Singh, P., Srinivas, K., and Srinivasa Rao, Ch (2012). Water requirement and use by Jatropha curcas in a semi-arid tropical location. Journal of biomass and bioenergy 39 (2012): 175-181.

Lakew, H. and Shiferwa, Y., in Melka Mahiber, 2008. Rapid assessment of biofuels development status in Ethiopia and proceedings of the national workshop on environmental impact assessment and biofuels. Addis Ababa, Ethiopia: MELCA Mahiber. 
Land Matrix (2012). The online public land deals database, http://landportal.info/landmatrix, accessed 01 May 2012).

Makki, F. and Geisler, C. 2011. Development by dispossession: Land grabbing as new enclosures in contemporary Ethiopia. Paper presented at the International Conference on Global Land Grabbing, Institute of Development Studies and Future Agricultures Consortium, University of Sussex, Brighton, UK, 6-8 April 2011.

Milbrandt, A. and R. Overend, 2009. Assessment of biomass resources from marginal land in APEC economies. Report prepared for the Asia-Pacific Economic Cooperation Energy Working Group under EWG 11/2008A. APEC.

MoME (Ministry of Mines and Energy), 2007. Biofuel development and utilization strategy. Addis Ababa: The Federal Democratic Republic of Ethiopia.

Openshaw, K. 2000. Review of Jatropha curcas: an oil plant of unfulfilled promise. Biomass and Bio energy 19(1): 1-15.

Pandey,Ch., Singh, Kr., Singh, Sh., Kumar, A., Singh,B., Singh, R. (2012).Jatropha curcas: A potential biofuel plant for sustainable environmental Development. Journal of Renewable and Sustainable Energy Reviews 16 (2012): 2870- 2883

Peterson, G. M., and J. K. Galbraith. 1932. The Concept of Marginal Land. American Journal of Agricultural Economics 14(2): 295.

Principles for Responsible Agricultural Investment (PRAI, 2010). Principles for Responsible Agricultural Investment that Respects Rights, Livelihoods and Resources. A discussion note prepared by FAO, IFAD, UNCTAD and the World Bank Group to contribute to an ongoing global dialogue.

Rachel, A. N. \& Dana, M.B., 2012. Marginal land: the role of remote sensing in constructing landcapes for agrofuel development. Journal of Peasant Studies 39(2): 403-422

Rahmato,D., 2011. Land to Investors: Large-scale land transfer in Ethiopia. Forum of Social Studies (FSS) Addis Ababa, FSS Policy Debate Series No.1.

Renner, R. (2007). "Green Gold in a Shrub." Scientific American 296(6): 20-23

Rizzo, M. (2006). What was left of the groundnut scheme? Development disaster and the labour market in Southern Tanganyika 1946-1952. Journal of Agrarian Change 6(2): 205238.

Sarathum, S., Hegele , M. \& Wünsche, J.N., 2011. Micropropagation of jatropha curcas L., Acta Horticulturae (ISHS) 923:65-72, http://www.actahort.org/books/923/923_8.htm.

Schut, M., Slingerland, M., and Locke, A. (2010). Biofuels development in Mozambique. Update and analysis of policy, potential and reality. Journal of Energy Policy 38 (2010) :5151-5156.

The Financial Express, 2009. Emami's strength lies in diversified investment. The Resource Centre.

The State of Food and Agriculture (FAO), 2008. Biofuels: prospects risks and opportunities services. Food and agriculture organization of the united nations, Rome. 
Trivedi, S., Gaudani, H., Gupta, M., Gupta, N., Patil, P., Gupta, G., Krishna, V., and Reddy, P. (2012). Establishment of Agrobacterium-mediated genetic transformation in Jatropha curcas L. The International Journal of Agriculture Sciences 1 (2):11-20.

UN-Energy. 2007. Sustainable bioenergy: A framework for decision makers.

United Nations, New York. Available at http://www.fao.org/docrep/010/ a1094e/a1094e00.htm (accessed 13 July 2012).

Yanga, Cheng-Yuan, Fang, Zhen, Li,. Bo, and Long Yun-feng (2012). Review and prospects of Jatropha biodiesel industry in China. Journal of Renewable and Sustainable Energy Reviews 16 (2012): 2178- 2190

World Bank (2010). Rising Global Interest in Farmland. Can it Yield Sustainable and Equitable Benefit. The World Bank. 